\title{
Identity politics in Social Media in the 2019 Presidential Election
}

\author{
Moh. Aris Munandar ${ }^{1}$, Suyahmo $^{2}, \&$ Andi Suhardiyanto $^{3}$ \\ \{moharis.pkn@mail.unnes.ac.id ${ }^{1}$ \} \\ Universitas Negeri Semarang, Indonesia ${ }^{1,2,3}$
}

\begin{abstract}
Identity politics is an important issue in contemporary Indonesian politics. The use of religion and ethnic labels has become one of the agendas in winning elections. Especially with the existence of social media that actively spreads the idea of identity politics. This research itself was carried out by analyzing qualitatively issues of identity politics that are rife in social media. As a result, identity politics in the 2019 presidential election then illustrates that the issue of identity is becoming increasingly widespread in political contestation in Indonesia.
\end{abstract}

Keywords: Identity politics, Social Media, Presidential Election

\section{Introduction}

There are two terminology of identity politics; 1 ) identity of politics that identifies identities that arise from political activities, and 2) identity politics that identifies political identities united in one ideal [1] furthermore Machdani also represents political identity that has a political meaning of difference, political experience, and multicultural politics. Syafii [2] social scientists were interested in identity politics around 1970, they discussed gender, race, ethnicity and other marginalized social groups. The further discussion extends to issues of religion, beliefs and diverse cultural ties. He also stated that identity politics used in local politics were more colored by the motivation of the local elite to appear. Cartwright in Machdani Afala [1] Based on political sources identity is divided into two; namely 1) essentialist, namely identity politics whose source is inherent in itself, the entity is as it is; and 2) constructivism, namely the identity politics that states the entity is the result of construction and can develop.

Identity politics in Indonesia is interesting to study because in the presidential election issues concerning certain identities have been raised. NKRI versus the Khilafah, Reunion of 212, Islamic Archipelago (Islam Nusantara) versus Arabic Islam (Islam Arab) or the emergence of religious identity in the political stage in Indonesia. his condition as studied by Tarasiewicz [3] the relationship between politics and religion always raises various problems, one of which is the problem of separation between state and religious affairs, there are countries that adhere to strict separation, but there are countries that embrace loose separation. Similarly, what Aronowitz [4] said, identity politics refers to social group behavior rather than individual behavior so that the identity that emerges is the identity of a group such as gender, ethnicity, certain religious groups, and certain sexual orientation groups. Whereas Jayer S.M [5] stated that identity politics is included in the political sphere of the movement. Identity politics criticizes a socio-political condition of the community. Gutman in Syafii [2] stated that identity politics seen in the Martin Luther King and Catholic Bishops in Latin America is actually more 
driven by social justice arguments than religious reasons. How about in Indonesia? Religious groups, especially Islam in Indonesia, feel politically and economically marginalized compared to other religious groups. In the political field, certain Islamic groups have the idea that Islamic law (Islamic law) must be applicable in the Indonesian legal system, although Islamic figures such as Gus Dur and Nurkholis Majid try to synergize nationalist interests with Islamic interests, by stating Islamic values that must be offered not a formalist Islam so that it appears scripturalist (written), and cultural.

\section{Research Methods}

This research used the method of phenomology and framing, studying trends that emerge on social media related to the 2019 presidential election in Indonesia. Social media used because formal media tends to only target one candidate pair, while the other candidate pair is not reported, so that social media becomes a media for balancing news between pairs of presidential candidates. There is a problem when using social media as a study, that is, between valid news and hoaxes is very difficult to distinguish, so that triangulation is still used by formal media for information checking. Social media learned from Youtube with accounts: Yasfi ken, GPS, Iqra 212, AF Citizen, Layar Merah, Rumah Ide, Reborn, Benteng Aqidah, Anak Bangsa, Berita Pilihan, Hitz Info, Primary TV, Imran Prasetyo Official, Sandiaga Uno Lovers, and Macan Idealis.

\section{Identity Politics and Social Media}

There were two candidate pairs in the Indonesian Presidential Election in 2019, they were Joko Widodo-Makruf (01) and candidate pair of Prabowo-Sandi (02). In the campaign, it appeared that the formal media of television were more dominated by candidate pair 01 , this is because as incumbent, the candidate pair 01 had more access to formal media than the pair 02 . In addition, formal media are owned by many people supporting pair 01. Consequently, the activities of candidate pair 02 were less likely to be exposed by formal media. Even the formal media seemed co-opted so as not to spread the activities of candidate pair 02 to the audience. As a result, the pair of candidates 02 preferred alternative media to disseminate their political ideas.

Alternative media chosen by candidate pair 02 to disseminate their political ideas was social media via the internet. Price \& Capella [6] the use of online media is an opportunity in politics, then he put forward the concept of teledemocracy that is democracy using the internet. William et al [7] the use of the internet will be vital in political campaigns. Bakery \& Kalnes [8] suggested net politics, namely politics through the internet; online election campaign which is an online election campaign; viral networking is a network to neutralize ideas online.

The limitation of using formal mass media made candidate pair 02 expressed their identity that the group had limited facilities and infrastructure in campaigning, whereas candidate pair 01 had adequate campaign facilities and infrastructure and had the support of facilities and infrastructure from various parties. This condition as stated by D'Cruz [9] identity politics is useless if it cannot answer who I am, who you are and various other possibilities. Thus identity politics uses the paradigm of social definition, trying to define itself and be defined by others as Mead's expression that the human self is contained in subjects (I) and objects (me) [10]. 
The use of social media often does not come from official sources of the campaign teams of candidate pairs 01 and 02 . The campaign team of candidate pair 01 is called TKN while the pair of candidate 02 is called BPN. In the 2019 Presidential Election campaign there were volunteers. The volunteer is a group of people who provide support to one of the candidates to influence the other party to choose the candidate they support; the volunteer is officially registered by the campaign team of each candidate pair. The use of social media is more likely to use identities that do not originate from the campaign team or volunteer candidate pairs. Accordingly, to find out whether the uploads are in favor of 01 or 02 , it is known from the idea contents' alignments. If the contents of the ideas are more inclined to provide information on candidate pair 01 , then categorized as supporting 01 and vice versa.

As a result, there was a heated conflict on social media between supporters 01 and 02 , each party uploading information in a monologue rather than dialogical fashion, each more likely to topple each other. Each party felt slandered by the other party. The social media used in the 2019 presidential election was more accurately referred to as "digital story telling" because the social media used in the campaign was structured as a coherent story with a specific theme. This condition was revealed by Burges (2007: 192-193) in Bakery \& Kalnes [8] the content of social media related to digital politics is more likely to be arranged in a story that is coherent with a particular political vision

\section{Framing of Identity Politics in Social Media During the Presidential Election 2019}

A fact can be highlighted differently by a media, for example related to the Palestinian and Israeli case, the same incident by two newspaper media (Kompas and Republika) is displayed differently; Republika considered Israel as a Palestinian invader while Kompas newspaper media considered the peace agreement between Israel and Palestine as something important and must be continuously pursued [11]. Framing is what is highlighted and what is omitted in the news. Framing is similar to rational choice theory, where when people are faced with several types of choices, people will make choices that are likely to have the best results [12] and [13]. Framing is a social construction of the media in expressing facts. Framing is a way of seeing how the media tell stories (story telling). Framing as a social construction is in accordance with the ideas of Berger \& Luckman [14] that humans and society are dialectical, dynamic and plural products continuously.

Framing related to identity politics in Social Media in the 2019 Presidential Election; divided into pre-election, campaign period and post-election. Then explained as follows:

Tabel 1. Framing of Identity Politics in Social Media in Pre-Presidential Election 2019

\begin{tabular}{|c|c|c|c|}
\hline No. & Joko Widodo's Party & No & Prabowo Subianto's Party \\
\hline 1 & Covert use of state recources & 1 & Own strength \\
\hline 2 & $\begin{array}{l}9 \text { dragons' assistance (conglomerate } \\
\text { of Chinese descent) }\end{array}$ & 2 & Native \\
\hline 3 & President is not changed & 3 & 2019 changing a president \\
\hline 4 & Defamed & 4 & Defaming \\
\hline 5 & Law enforcement & 5 & $\begin{array}{l}\text { The apparatus is not neutral especially } \\
\text { the police }\end{array}$ \\
\hline 6 & $\begin{array}{l}\text { Nationalist, traditional and non- } \\
\text { islamic }\end{array}$ & 6 & 212 alumni and exclusive group \\
\hline 7 & Cebong & 7 & Kampret \\
\hline
\end{tabular}


$8 \quad$ Left-wing political people

$8 \quad$ Anti-left-wing political people

Source: processed from observation and documentation data

Tabel 2. Framing of Identity Politics in Social Media during the Presidential Election Campaign 2019

\begin{tabular}{|c|c|c|c|}
\hline No & Joko-Makruf's Party & No & Prabowo-Sandi's Party \\
\hline 1 & Success in Building infrastucture & 1 & Facilities are not for the poor people \\
\hline 2 & $\begin{array}{l}\text { Corporate actors' collusion with foreign } \\
\text { capital and large investors }\end{array}$ & 2 & $\begin{array}{l}\text { Natural resources must be managed by } \\
\text { natives and for the welfare of the people }\end{array}$ \\
\hline 3 & $\begin{array}{l}\text { Supported by nationalist groups, } \\
\text { traditional Islam and non-Islam }\end{array}$ & 3 & $\begin{array}{l}\text { Supported by modernist Islamic groups, } \\
\text { Arab descendants, true Nationalists }\end{array}$ \\
\hline 4 & Santri, mothers' group, poor people & 4 & $\begin{array}{l}\text { The Power of Emak-Emak (Mothers } \\
\text { group) }\end{array}$ \\
\hline 5 & Scrambling for wrapped rice & 5 & $\begin{array}{l}\text { Food participation comes from campaign } \\
\text { communities }\end{array}$ \\
\hline 6 & $\begin{array}{l}\text { Many cards; unemployment card, } \\
\text { college card }\end{array}$ & 6 & Use of KTP for social programs \\
\hline 7 & Visited by a few masses & 7 & Visited by many masses \\
\hline 8 & The Prices of staple food are affordable & 8 & The prices of staple food is expensive \\
\hline 9 & Considedered many broken promises & 9 & More able to fulfill promises \\
\hline 10 & Soft and friendly & 10 & $\begin{array}{l}\text { Blokosutho (as he is) and firm, some even } \\
\text { neutralize like Umar bin Khatab. }\end{array}$ \\
\hline 11 & $\begin{array}{l}\text { The vice-presidential candidate is } \\
\text { considered weak }\end{array}$ & 11 & $\begin{array}{l}\text { The vice-presidential candidate is } \\
\text { energetic, agile and vibrant }\end{array}$ \\
\hline 12 & Close to the people (Populist) & 12 & $\begin{array}{l}\text { Presidential candidate is considered distant } \\
\text { from the people }\end{array}$ \\
\hline 13 & Behaving based on Pancasil & 13 & $\begin{array}{l}\text { Considered supported by supporters of the } \\
\text { Khilafah }\end{array}$ \\
\hline 14 & $\begin{array}{l}\text { Considered to use BUMN, Government } \\
\text { facilities }\end{array}$ & 14 & Own means \\
\hline 15 & $\begin{array}{l}\text { Considered formal media co-optation, } \\
\text { especially television }\end{array}$ & 15 & $\begin{array}{l}\text { Only one television media is considered } \\
\text { balanced }\end{array}$ \\
\hline 16 & $\begin{array}{l}\text { It is always reported that electability is } \\
\text { higher than other party by quick count } \\
\text { agencies }\end{array}$ & 16 & $\begin{array}{l}\text { It is always reported to lose electability and } \\
\text { considers the quick count institution to be } \\
\text { funded by one of the camps. }\end{array}$ \\
\hline 17 & Many national figures as supporters & 17 & Few national figures as supporters \\
\hline
\end{tabular}

Source: processed from observation and documentation data.

Tabel 3. Framing of Identity Politics in Social Media in Post-presidential Election 2019

\begin{tabular}{|c|c|c|c|}
\hline No & Joko-Makruf's Party & No & Prabowo-Sandy's Party \\
\hline 1 & $\begin{array}{l}\text { Considered victorious by the quick count } \\
\text { agency }\end{array}$ & 1 & $\begin{array}{l}\text { Considering the quick count institution } \\
\text { approved by the partisan KPU is in favor one } \\
\text { of the parties }\end{array}$ \\
\hline 2 & $\begin{array}{l}\text { Considered designing electoral fraud } \\
\text { structured systematically and massive. }\end{array}$ & 2 & Considered framing Election fraud \\
\hline 3 & $\mathrm{KPU}$ is not cheating & 3 & $\begin{array}{l}\text { KPU is cheating, the wrong input } \mathrm{C} 1 \text { always } \\
\text { harms the party of } 02 \text {, there have been } \\
\text { thousands of wrong inputs }\end{array}$ \\
\hline 4 & $\begin{array}{l}\text { Inviting parties and other figures to join } \\
\text { the incumbent coalition }\end{array}$ & 4 & The Broken supporters' solidity issue \\
\hline 5 & Trust the KPU & 5 & $\begin{array}{l}\text { Escorting } \mathrm{C} 1 \text {, watching the count, Candidate } \\
\text { pair } 02 \text { wins based on internal calculations }\end{array}$ \\
\hline
\end{tabular}


6 Law enforcement

7 Considered authoritarian; siding apparatus

8 Inviting to accept defeat and win legowo
6 People Power

7 Fighting for democracy with the power of the people

8 Considered unable to accept defeat, the issue of cheating

Source: processed from observation and documentation data

Based on the explanation in Table 1, the framing used has the nuances of the stronghold 01 using the power of the state for the benefit of the president, even the president is considered to use the power of the state for his political interests. This framing then continued during the campaign period of Table 2 that incumbents used state power for political purposes such as using BUMN, civil apparatus, village officials to mobilize the masses. Even Framing Table 3 of the election implementing agencies is no longer reliable. This condition is worrying because it has targeted the institutional elections; when the election management agency (KPU), the Election Supervisor (Bawaslu), the MK (election dispute adjudicator), and the police are considered to have taken sides and have the tendency to win one of the parties. This condition is very alarming, and deadlocks can occur in politics in Indonesia, plus the framing of people power. Election institutions must show a dignified and trusted performance so that trust from all camps can grow.

The programs of each candidate pair are not so intensely displayed on social media. What the candidate will do is not very detailed, even more visible are the principles of state management; for example, candidate pair 02 chooses to make us more independent and debt free, candidate pair 01 is more realistic in choosing debt but well managed. How to be debt free is not so detailed to be told (story telling).

In the 2019 presidential election each candidate pair had innovative ways to attract the masses. Candidate Pair 02 uses the song "the power of emak-emak" which features young mothers with lyrics shifting their political choices to Prabowo Sandi. Reach new Indonesia. The power of emak-emak song with visualization of upper middle-class mothers, made Prabowo Sandi popular among mothers of urban identity. The use of songs for the campaign of candidate pair 01 was less likely than candidate pair 02 .

Candidate pair 01 conducted framing if they are very populist, they are very close to the small people, and even try to keep the state's attention to the needs of the poor people such as the need for schools, health needs by giving cards as social action. Pair of candidate 02 in the framing distance from the people, greets people in the car instead of getting out of the car, Framing distance with the people, answered by framing of the vice presidential candidate 02 , Sandiaga who always greets his masses with joint gymnastics, running together and singing together as an effort to get closer to the people.

Identity politics that was raised in the 2019 Presidential Election is more directed towards constructivism identity politics than essentialist identity politics. Thus, the identity that is raised is the result of construction and can develop such as the power of mother, anti-neo-colonialist and anti-neo-imprealist, defenders of truth, people's power, defenders of democracy, new Indonesia, independence, oppression, lower, middle and upper economic structures, etc.

\section{Conclusions}


Identity politics intends to learn the identities that arise in political activities, then these identities carry out political movements to change a condition for the better. Usually the movement is carried out by marginalized groups. Besides that, identity politics also intends that these identities can be combined with shared values such as nationalism. Social media for political activities can be referred to as the political net or teledemocracy, because in the future, people will inevitably tend to use the internet to spread political ideas and mobilize mass political campaigns.

Identity politics that emerged in the 2019 presidential election is more directed towards constructivism identity politics than essentialists. Entities try to do construction on certain issues, so that finally the entity against the parties of friends and opposing parties.

\section{References}

[1] L. Machdani Afala, Politik Identitas di Indonesia. UB Press, 2018.

[2] A. S. Maarif, A. S. Maarif, I. Ali-Fauzi, and S. R. Panggabean, Politik identitas dan masa depan pluralisme kita. Centre for the Study of Islam and Democracy, 2010.

[3] F. P. Tarasiewicz, "Between Politics and Religios In Search of The Golden Mean.," Stud. Gilsomana, 2012.

[4] S. Aronowitz, The politics of identity: Class, culture, social movements. Routledge, 2014.

[5] S. M. Jayer, "The Identity politics; History, Nationalism and The Prospect of Peace in Post Cold War East Asia," Carlisthe, PA, Strateg. Stud. Inst., 2007.

[6] V. Price and J. N. Cappella, "Online deliberation and its influence: The electronic dialogue project in campaign 2000," IT Soc., vol. 1, no. 1, pp. 303-329, 2002.

[7] A. P. Williams, K. D. Trammell, M. Postelnicu, K. D. Landreville, and J. D. Martin, "Blogging and hyperlinking: Use of the Web to enhance viability during the 2004 US campaign," Journal. Stud., vol. 6, no. 2, pp. 177-186, 2005.

[8] Q. Bakery, Eva \& Kalnes, “The Hadia Story: Digital Story Telling in Election Campaign,” Int. J. Media Technol. Life Long Learn., vol. 6, no. 2, 2010.

[9] C. D'Cruz, Identity politics in Decontruction: Calculating With The incalculable. Berlin: Ashygate Publishing Company, 2008.

[10] D. R. I. B. Wirawan, Teori-teori Sosial dalam Tiga Paradigma: fakta sosial, definisi sosial, dan perilaku sosial. Kencana, 2012.

[11] Eriyanto, Analisis Framing; Konstruksi, Ideologis dan Politik Media. Yogyakarta: LKIS, 2012.

[12] D. Marsh and G. Stoker, "Teori dan metode dalam ilmu politik," Bandung Nusa Media, vol. 82, 2010.

[13] G. F. Gaus and C. Kukathas, "Handbook Teori Politik," Bandung Penerbit Nusa Media, 2012.

[14] P. L. Berger, F. M. Parera, and T. Luckman, Tafsir sosial atas kenyataan: Risalah tentang sosiologi pengetahuan. LP3ES, 1990. 